\title{
TRANSFORMASI BELAJAR DAN PEMBELAJARAN MENUJU ABAD ABAD XXI
}

\begin{abstract}
Oleh Sutiah *
Pengembangan pola belajar dan pembelajaran diarahkan pada empat pilar secara utuh yaitu, belajar untuk mengetahui (learning to know), belajar untuk berbuat (learning to do), belajar untuk menjadi jati diri (learning to be), dan belajar untuk hidup bersama (learning to life together). Keempat pilar ini pada abad XXI harus dikembangkan secara integrative agar mampu mengeluarkan out put yang refresentatif
\end{abstract}

Kata Kunci: Transformasi, Belajar, Pembelajaran

\section{Pendahuluan}

Kondisi proses belajar dan pembelajaran di lembaga-lembaga pendidikan sampai saat ini relatif belum banyak mengalami perubahan, walaupun kemajuan ilmu pengetahuan dan teknologi komunikasi dan informasi telah lama menyentuh dunia pendidikan. Seharusnya kemajuan ilmu pengetahuan dan teknologikomunikasi dan informasi dapat dimanfaatkan untuk pengembangan pola belajar dan pembelajaran yang dapat mendorong proses belajar secara lebih cepat, dinamis, eksploratif, akseleratif, dan menyenangkan.

Kebanyakan pola belajar dan pembelajaran yang berkembang di lembagalembaga pendidikan masih relatif mengandalkan buku teks, lembar kerja siswa, dan ceramah atau diskusi yang tidak terstruktur, sedangkan aktivitas belajar terkesan DDDCH (datang, duduk, dengar, catat, dan hafal/hilang). Kondisi ini diperparah oleh kesiapan pebelajar untuk mengikuti kegiatan belajar- mengajar dengan pengalaman dan pengetahuan yang sangat terbatas (prior knowledge). Dan yang lebih memprihatinkan lagi, tidak jarang orientasi bealajar dan pembelajaran hanya untuk mengejar perolehan sertifikat indeks prestasi belajar (IPK) atau NEM di sekolah/ madrasah., tapi belum membangun kompetensi diri secara utuh untuk mempersiapkan sikap, kemampuan, dan kecakapan hidup yang dibutuhkan dalam kehidupan di masa depan peserta didik..

Karena itu diperlukan tranformasi dalam belajar dan pembelajaran, yakni perubahan wajah dan watak atau sikap terhadap pola-pola belajar dan pembelajaran sebagai akibat terjadinya interaksi sistem belajar dan pembelajaran dengan tuntutan

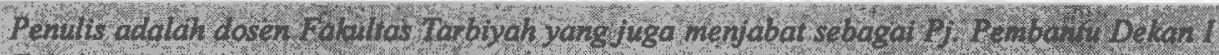
Fakulias Uils Malang. Kini Lercatat sebagai Peserta Program Dolaor Univ Neger Valang. 
perubahan dan perkembangan ilmu pengetahuan dan teknologi. Perubahan harus dilakukan untuk memperbaharui pola belajar dan pembelajaran khususnya di lembaga-lembaga pendidikan persekolahan dengan menciptakan kondisi belajar yang memungkinkan pebelajar dapat mengembangkan keutuhannya sebagi pribadi yang memiliki keluasan ilmu, mampu mengaplikasikan dan mengamalkan ilmunya, dapat menemukan dan menjadi dirinya sendiri sebagai manusia beragama, berilmu, bermoral, dan bersosial serta dapat hidup dan memberikan kemasalahatan dalam kehidupan bersama. Pembelajaran diarahkan untuk memiliki wawasan global, wawasan yang berprespektif masa depan, berpikir kritis-inovatif-kreatif, berimajinasi, berinterpretasi, berpikir holistic, imperatif, produktif, dan tidak dikotomis. Pengembangan pola belajar dan pembelajaran diarahkan pada empat pilar secara utuh yaitu, belajar untuk mengetahui (learning to know), belajar untuk berbuat (learning to do), belajar untuk menjadi jati diri (learning to be), dan belajar untuk hidup bersama (learning to life together), UNESCO (1994),

Menurut Dalin dan Rust, sebagaimana yang dikuitip Rasiyo, bahwa pendidikan yang baik adalah yang mampu menyiapkan anak untuk menempuh dan menjawab masa depannya. Dan untuk mencapai kondisi semacam itu pola belajar dan pembelajaan harus mampu mengembnagkan potensi anak secara optimal sesuai perkembangan dan tuntuna kondisi masyarakatnya. Karena itu diperlukannya transformasi atau perubahan sikap untuk memperbaharui pola belajar dan pembelajaran di lembaga-lembaga pendidikan sesuai tuntutan belajar dan pembelajaran di abad XXI atau disebut sebagai abad ilmu pengetahuan

\section{Tuntutan Abad Imu Pengetahuan}

Pada abad ilmu pengetahuan, pengembangan segala sesuatu didasarkan pada ilmu pengetahuan dan teknologi. Hal ini berarti pengembangan segala sesuatu yang tidak berbasis ilmu pengetahuan dan teknologi akan tergeser, terpinggirkan, bahkan tergusur. Pengembangan sosial, budaya, ekonomi, politik, bahkan agama sekalipun harus bertumpu pada ilmu pengetahuan. Peter Druckes dalam New Realities memaklumkan kehadiran masyarakat berpengetahuan yang akan melanjutkan atau malah menggantikan dominasi masyarakat industrial, masyarakat pertanian (praindustrial), dan masyarakat pra-pertanian. Dalam kehidupan bermasyarakat, orang yang tanpa berpengetahuan niscaya akan tergeser dan terpinggirkan karena tidak mampu berkiprah dalam berbagai aktivitas utama kehidupan manusia. Sedangkan masyarakat yang berpengetahuan akan unggul dan berjaya karena mereka akan mampu melaksanakan berbagai aktivitas utama kehidupan. Hal ini menunjukkan bahwa pengetahuan dan teknologi merupakan modal dasar keunggulan dalam abad pengetahuan. Dan orang-orang yang mampu belajar dan menguasai pengetahuan dan teknologi akan unggul dan berjaya di abad pengetahuan.

Thomas A. Stewart dalam Intellectual Capital (1997), menegaskan 
pentingnya peranan pengetahuan atau intelektual dalam abad pengetahuan. Dengan modal ilmu pengetahuan dan teknologi yang unggul, seseorang atau sekelompok masyarakat akan tetap eksis, unggul, berjaya, dan mampu berkiprah lebih berarti dalam berbagai bidang kehidupan mutakhir. Sebaliknya, orang atau sekelompok masyarakat yang bermodal pengetahuan terbatas, pas-pasan, apalagi usang akan terancam, terpinggirkan, atau boleh jadi tergusur dari bidang kehidupan mutakhir. Dengan perkataan lain manusia berpengetahuan akan lebih unggul dan berguna, sedang manusia yang tidak berpengetahuan akan menjadi manusia terbelakang dan serba kalah.

Dalam perspektif al-Quran orang-orang yang berilmu pengetahuan akan memiliki kedudukan yang tinggi (ditinggikan derajanya) dapat berperan, unggul, berguna, berkuasa dan banyak memberikan manfaat serta kemaslahatan bagi umat manusia, lingkungan, dan alam sekitarnya (QS As-Sajadah). Orang-orang yang berilmu pengetuan dalam al-Quran diibaratkan bagai pohon yang kokoh, akarnya menancap ke bumi, daun dan dahannya menjulang ke langit, dan buahnya bermanfaat bagi sekelilingnya. Dan orang yang berilmu pengetahuan dengan yang tidak berilmu pengetahuan secara retorik dipertanyakan oleh al-Quran "Samakah antara orangorang yang berilmu pengertuan dengan yang tidak berilmu pengetahuan. Bahkan perbandingan orang yang berilmu pengetahuan dengan yang tidak, diibaratkan sebagai sinar rembulan bagi yang berilmu pengetauan sementara orang-orang yang ahli beribadah tetapi tidak berilmu pengehuan hanya diibaratkan sebagai sinar bintang (Wafadlul 'aalimi alal aabidi, ka fadlil qamari ala alkawakibi).

Bank Dunia dalam The Quality of Growth (2000) mengemukakan bahwa sumber daya manusia yang berpengetahuan merupakan aset yang sangat berharga bagi pertumbuhan, perkembangan, dan pembangunan manusia dan masyarakat secara keseluruhan. Manusia dianggap sebagai aset paling utama dalam meningkatkan kualitas pertumbuhan dan pembangunan yang akan mendatangkan kesejahteraan. Dan tidak diragukan lagi bahwa manusia berpengetahuan, memiliki keterampilan, dan sikap bijaksana merupakan investasi paling berharga dalam abad pengetahuan dibanding fisik dan alam.

Sehubungan dengan itu, pengembangan dan peningkatan kualitas manusia dan ilmu pengetahuan menjadi tugas imperatif dan tantangan bagi semua individu, masyarakat, dan bangsa jika ingin tetap survive memasuki abad ilmu pengetahuan. Lembaga-lembaga pendidikan berkewajiban dan ikut bertanggungjawab secara akademik, moral, dan sosial untuk mempersiapkan SDM yang berkualitas. Setiap individu, masyarakat, dan bangsa ini harus memiliki komitmen dalam mengembangkan dan meningkatkan ilmu pengetahuan, keterampilan dengan memiliki watak dan moral yang baik agar tetap eksis dan bermartabat dalam hidup dan kehidupan di abad pengetahuan.

Pendidikan dan pembelajaran dipandang sebagai wahana utama dan vital 
dalam pengembangan dan peningkatan kualitas manusia. Pendidikan dan pembelajaran memiliki kedudukan, fungsi, dan peranannya sangat penting, bahkan strategis dan taktis. Maka sudah seharusnya pendidikan dan pembelajaran harus menjadi prioritas utama dalam pembangunan. Tidak kurang, berbagai negara di dunia menjadikan pendidikan dan pembelajaran sebagai prioritas utama pemabangunan. Ratu Elizabeth II dari Inggris, misalnya, dalam pidatonya di depan parlemen tanggal 14 Mei 1997 dengan tegas menyatakan: "Prioritas utama pemerintah sekarang adalah pendidikan. Pemerintah berusaha keras meningkatkan standar pendidikan di sekolah dan perguruan tinggi, serta berupaya menggalakkan program belajar terus-menerus di tempat kerja". Sekarang pun di bawah pemerintahan Partai Buruh, Tony Blair dengan gencar mengkampanyekan program utama politiknya bahwa tiga prioritas utama pemerintah Inggris saat ini adalah: Pendidikan, Pendidikan, dan Pendidikan. Deklarasi pemerintahan Bill Clinton dari Amerika Serikat juga memfokuskan program politiknya pada sistem pendidikan. Program politik berfokus pada pembenahan sistem pendidikan. Program ini juga dilanjutkan oleh George W. Bush seperti tertuang dalam cetak-biru [blueprint] program pendidikan pemerintahan Bush. Pemerintahan Jepang dalam buku Japan Education in Crisis, sedang sibuk menangani dan membenahi pendidikan dan pembelajaran karena merasa pendidikan Jepang berada dalam krisis. Negara Malaysia, Brunei Darussalam, dan Singapura juga memberikan prioritas utama program pendidikan dan pembelajaran sebagaimana tersirat dalam alokasi anggaran pendidikan dan kesungguhan membenahi berbagai aspek pendidikan dan pembelajaran. Jika kita ingin mengembangkan dan meningkatkan mutu SDM di abad ilmu pengetahuan ini, maka kita harus melakukan transformasi untuk memprioritaskan perbaikan kondisi belajar dan pembelajaran pendidikan kita saat ini. Karena pendidikan dan pembelajaran telah diyakini dan diakui sebagai pintu utama untuk mengembangkan dan meningkatkan mutu SDM dan ilmu pengetahuan.

Pendidikan dan pembelajaran akan dapat berfungsi sebagai pintu utama pengembangan dan peningkatan kualitas manusia dan pengetahuan yang dibutuhkan abad ilmu pengetahuan, apabila pola belajar dan pembelajaran yang dikembangkan sekarang ini dibenahi, diubah, atau diredesain agar sesuai [compatible] dengan tuntutan perkembangan ilmu pengetahuan. Perubahan belajar dan pembelajaran diperlukan karena pendidikan dan pembelajaran kita sekarang masih menyimpan beberapa kelemahan antara lain (1) pendidikan kita telah kehilangan objektivitas, (2) tidak mendewasakan subjek didik, (3) tidak menumbuhkan pola berpikir kritis, (4) tidak menghasilkan manusia terdidik, (5) masih dirasakan membelenggu, (6) belum mampu membangun individu belajar, (7) masih dirasakan linier-indoktrinatif, (8) belum mampu menghasilkan kemandirian, dan (9) belum mampu memberdayakan dan membudayakan peserta didik, (Djohar, 2003). Karena itu perlu dikembangkan pola belajar dan pembelajaran yang dapat membangun dan mengembangkan (1) 
pendidikan kecakapan hidup (life skill education), (2) membangun keutuhan kecerdasan intelektual (IQ), kecerdasan emosional (EQ), dan kecerdasan spritual (SQ), (3) membangun pendidikan demokratik, (4) pendidikan yang membangun dan menghormati HAM, (5) kemampuan memecahkan masalah dan mengelola konflik secara positif (psiedo education), dan (6) membangun keutuhan pribadi yang berbudaya.

\section{Pembelajaran Abad Industrial dan Abad Pengetahuan}

Dalam kajian teknologi pembelajaran, dewasa ini pola belajar dan pembelajaran telah mengalami pergeseran konsep yang berimplikasi pada model-model pelaksanaan proses belajar dan pembelajaran. Pada awalnya dunia pendidikan telah lama dikuasai oleh konsep belajar dan pembelajaran behavioristik yang menekankan stimulus-respon yang sama, sehingga siswa pasif, resptif dan tidak proaktif. Namun saat ini telah disadari pentingnya penerapan model-model belajar konstruktivistik yang lebih menekankan pada setting dan kebermaknaan dalam belajar, dan modelmodel belajar humanistic yang lebih menekankan pada pembelajaran berhulu dan bermuara pada manuasia (self actualization).

Perubahan paradigma belajar dan pembelajaran tersebut di atas melahirkan perbedaan model belajar dan pembelajaran yang sesuai dengan tuntutan belajar di abad ilmu pengetuan. Beberapa perbedaan model belajar dan pembelajaran abad industrial dan abad ilmu pengetahuan dideskripsikan Trilling dan Hood dalam Learning, Technology, and Education Reform in the Knowledge Age (1999) antara lain (1) pada abad industrial, guru sebagai pemimpin dan sumber belajar, sementara pada abad pengetahuan guru sebagai fasilitator, pembimbing, dan konsultan serta sebagai mitra belajar, (2) pada abad industrial, kurikulum belajar merupakan paket yang sudah tersusun, sementara pada abad pengetahuan kurikulum belajar dapat ditentukan bersama pebelajar, (3) pada abad industri, jadwal belajar ditetapkan secara kaku tidak ada celah, sementara pada abad pengetahuan jadwal belajar terbuka, fleksibel, sesuai permintaan pebelajar, (4) pada abad industrial, penentuan materi belajar didasarkan pada fakta, bersifat teori, abstrak, berpijak pada prinsip dan survei, dengan latihan dan praktik, sedanglan pada abad pengetahuan didasarkan pada projek pokok dan permasalahan pokok, dihubungkan dengan dunia nyata, bersifat kongkret, melakukan tindakan dan refleksi, serta penyelidikan dan mendesain, (5) pada abad industrial, segala sesuatu didasarkan pada peraturan dan prosedur serta diciptakan untuk berkompetisi, sedangkan pada abad pengetahuan dibangun semangat untuk mencari dan menemukan, mencipta, dan kolaborasi, (6) pada abad industrial, kegiatan belajar difokuskan pada kelas, hasil akhir belajar sangat menentukan, kegiatan harus sesuai norma, dan komputer sebagai subjek belajar, sedangkan pada abad pengetahuan difokuskan pada komunitas, hasil akhir belajar bukan semata-mata menjadi ukuran, perbedaan adalah 
hal kreatif, dan komputer sebagai alat kegiatan belajar, (7) pada abad industrial, penggunaan media tetap dan komunikasi terbatas dalam ruang kelas, sedangkan pada abad pengetahuan penggunaan multimedia interaktif dan komunikasi hingga ke duania luar, dan (8) pada abad industrial, tes dilaksanakan dan dinilai berdasarkan norma, sedangkan pada abad pengetahuan penilaian tes didasarkan atas performance, keahlian, penilaian oleh teman sebaya, kepenasihatan, dan keperibadian. Karena itu penerapan Kurikulum Berbasis Kompetensi (KBK) yang akan diberlakukan tahun 2004 nanti, model penilaian tidak didasarkan pada bentuk atau jenis penilaian paper dan pan (ujian tulis) tetapi secara utuh (penilaian berbasis kelas atau penilaian selama proses KBM di kelas dan keseharian) dengan menggunakan porto folio, dan uji performansi (uji keahlian atau keterampilan)

\section{Pembelajaran Tradisional dan Pembelajaran Mutakhir}

Perubahan pola belajar dan pembelajaran tradisional menuju pola yang lebih mutakhir juga dikemukakan oleh Thomas, Mergendoller, dan Michaelson dalam Project-Based Learning: A Handbook for Midle and High School Teachers (1999) mendeskripsikan ciri-ciri pembelajaran yang dibutuhkan sekarang sebagai berikut (1) dilihat dari fokus kurikulum, pembelajaran tradisional menekankan pada cakupan isi, pengetahuan fakta, dan belajar keterampilan dan isolasi, sedangkan pembelajaran mutakhir menekankan kedalaman pemahaman isi, penguasaan konsep dan prinsip, dan pengembangan keterampilan pemecahan masalah kompleks, (2) dilihat dari lingkup dan urutan penyampaian, pembelajaran tradisional mengikuti urutan kurikulum secara ketat, belajar dari unit ke unit, memusat dan befokus serta berbasis pada disiplin, sedangkan pembelajaran mutakhir mengikuti minatsi belajar, unit-unit terbentuk dari problem dan isu yang kompleks, meluas, dan berfokus pada interdisipliner, (3) dilihat dari perannya, pembelajaran tradisional menempatkan guru sebagai penceramah, pemimpin, dan tenaga ahli dalam pembelajaran, sedangkan pembelajaran mutakhir menempatkan guru sebagai penyedia berbagai sumber belajar, sebagai partisipan, dan mitra belajar, (4) dilihat dari fokus pengukuran, pembelajaran tradisional menekankan pada hasil, skor tes, membandingkan dengan yang lain, atau kemampuan mereproduksi informasi, sedangkan pada pembelajaran mutakhir menekankan pada proses dan hasil, pencapaian nyata, unjuk kerja standar dan kemajuan dari waktu ke waktu, (5) dilihat dari bahan pembelajaran, pembelajaran tradisional mengandalkan buku teks, ceramah, dan presentasi, serta kegiatan dan lembar pelatihan dikembangkan guru, sedangkan pembelajaran mutakhir menekankan pada sumber-sumber belajar asli tercetak, interviw, dokumen, serta data dan bahan dikembangkan oleh si belajar, (6) dilihat dari penggunaan teknologi, pembelajaran tradisional menggunakan teknologi sebagai penopang, bersifat periferal, dijalankan oleh guru sebagai alat presentasi, sedangkan pembelajaran mutakhir penggunaan teknologi menjadi utama, bagian integral, diarahkan untuk 
pebelajar, dan digunakan untuk membantu presentasi pebelajar atau menguatkan pengetahuan pebelajar, (7) dilihat dari konteks kelas, pembelajaran tradisional menugasi pebelajar untuk bekerja sendiri, mendorong kompetisi, dan atau menerima informasi dari guru, sedangkan pembelajaran mutakhir menugasi pebelajar untuk bekerja dalam kelompok, terjadi kolaborasi satu dengan yang lain, pebelajar mengkonstruksi, memberikan kontribusi, dan melakukan sintesis informasi, (8) dilihat dari peranan pebelajar, pembelajaran tradisional memperlakukan pebelajar agar menjalankan perintah guru, mengingat dan mengulang fakta, menerima dan menyelesaikan tugas-tugas laporan, sedangkan pembelajaran mutakhir menempatkan pebelajar dapat melakukan kegiatan belajar yang diarahkan oleh dirinya sendiri, mengkaji, mengintegrasikan, dan menyajikan, pebelajar menentukan tugasnya sendiri dan bekerja secara independen dalam waktu yang besar, (9) dilihat dari tujuan pembelajaran, pembelajaran tradisioanl memiliki tujuan jangka pendek pebelajar mengetahui fakta, istilah, isi dan tujuan jangka panjangnya memiliki pengetahuan yang luas, dan dapat berhasil menyelesaikan tes standar pencapaian belajar, sedangkan pembelajaran mutakhir memiliki tujuan jangka pendek pebelajar memahami dan mengaplikasikan ide dan proses yang kompleks dan tujuan jangka panjangnya memiliki pengetahuan yang mendalam, berwatak, dan terampil mengembangkan kompetensi diri, mandiri, dan mau belajar sepanjang hayat.

\section{Pembaharuan Pola Belajar dan Pembelajaran}

Pembaharuan pola belajar dan pembelajaran dalam upaya meningkatkan kualitas dan mutu pendidikan kita yang sampai saat ini ini belum begitu menggembirakan merupakan suatu keniscayaan. Hasil survei pembangunan bidang pendidikan oleh Human Development Index (HDI), Indonesia ditempatkan pada peringkat 102 dari 106 negara. The Third International Mathematiccs and Science Studi-Repeat juga melaporkan bahwa siswa SLTP Indonesia menempati peringkat 32 untuk IPA dan 34 untuk matematika, dari 38 negara yang disurvai di Asia, Australia, dan Afrika (Depdiknas, 2001). Kondisi tersebut harus kita sikapi secara realistis. Harus diakui bahwa mutu dan kualitas pendidikan di Indonesia masih rendah. Menurut Rasiyo, (2002)rendahnya mutu dan kualitas pendidikan kita tidak dapat dilepaskan dari masih rendahnya menajemen pendidikan, kompetensi guru dan pengelolaan belajar mengajar. Memang tidak realistis dalam kondisi sistem belajar dan pembelajaran di lembaga-lembaga pendidikan kita seperti keadaan sekarang ini akan mampu melahirkan sumber daya manusia yang tangguh, andal, mampu merespon percepatan perkembangan iptek, mampu menopang reformasi dan pembangunan nasional, serta dapat melahirkan manusia-manusia yang mampu bersaing dan survival di abad global. Karena itu Dryden dan Vos (1999) dan Tilaar, mengemukakan revolusi pola pendidikan dan pembelajaran perlu dilaksanakan sebagai terobosan untuk meningkatkan mutu pendidikan di Indonesia. Bappenas 
(2001), Buchori (2001), dan Suparno dkk. (2002) menyatakan bahwa reformasi pendidikan dan pembelajaran perlu dilakukan supaya pendidikan dan pembelajaran dapat secara fungsional dan signifikan serta optimal menjadi wahana pengembangan dan peningkatan kualitas manusia dan ilmu pengetahuan serta keterampilan yang dibutuhkan pada abad sekarang.

Hal lain yang mendukung diperlukannya pembaharuan pola belajar dan pembelajaran tersebut antara lain:

1. Hasil kajian belajar dan gaya belajar (learning sylle). Informasi tentang gaya belajar sangat penting bagi guru atau dosen untuk menentukan bentukbentuk hubungan dan tingkatan komunikasi yang akan dikembangkan bersama peserta didik. Pemahaman terhadap gaya belajar menjadi hal penting untuk diketahui karena beberapa alasan (Eanes, 1997). Pertama, dosen dapat membantu mahasiswa mengembangkan kesadaran dan menghargai kekuatan belajar dan kecerdasan mereka. Kedua, dosen dapat mengambil keputusan tentang bahan/materi, metodologi, dan strategi pembelajaran. Ketiga, dosen dapat membantu mahasiswa dengan mengembangkan penghargaan terhadap perbedaan gaya belajar di antara mereka dengan menunjukkan bahwa perbedaan itu memiliki kekuatan yang dapat mendukung keberhasilan belajar bersama. Keempat-yang terpenting- adalah kesadaran bahwa gaya belajar dosen mungkin bukan merupakan gaya belajar mahasiswa.

Konsep tentang gaya belajar memahamkan bahwa tiap peserta didik memiliki gaya belajar yang berbeda yang tentunya membutuhkan perlakuan yang berbeda. Tidak seorang siswa/ mahasiswa pun dapat dikatagorikan bergaya belajar tertentu secara tepat. Akan tetapi, guru/dosen dapat membantu menumbuhkan kesadaran akan kecenderungan gaya belajarnya melalui pengamatan (observasi), mengajukan pertanyaan-pertanyaan, melakukan diskusi atau presentasi, dan membantu mereka melakukan karakterisasi. Secara umum, gaya belajar yang berkembang dengan segala karakternyadibedakan menjadi tiga macam, yaitu gaya global, analitik, dan kombinasi.

Eanes (dalam Dryden, 1999) mengidentifkasikan karaktristik peserta didik untuk mengetahui apakah bergaya belajar global, analitik, atau kombinasi keduanya. Karakteristik kedua gaya belajar tersebut adalah (1) seseorang yang memiliki gaya belajar global lebih mudah mengingat apa yang dilihat, disentuh dan dirasakan, sedangkan yang bergaya belajar analitik mudah mengingat apa yang didengar, (2) seseorang yang bergaya belajar global membuat keputusan berdasarkan emosi dan intuisi, sedangkan yang bergaya belajar analitik membuat keputusan berdasarkan logika, fakta, dan "daya pikir, (3) 'seseorang yang bergaya belajar global mudah mengingat tempat dan wajah, sedangkan yang memilki gaya belajar analitik mudah mengingat fakta dan nama, (4) seseorangyang bergaya belajar global bekerja tanpa perencanaan 
(spontan), sedangkan yang bergaya belajar analitik bekerja melalui perencanaan yang baik, (5) seseorang yang bergaya belajar global suka bekerja di lingkungan yang tidak teratur/ tak rapi, sedangkan yang bergaya belajar analitik suka bekerja di lingkungan yang teratur/ rapi. (6) seseorang yang bergaya belajar global suka mengerjakan banyak hal dalam satu kesempatan, sedangkan yang bergaya belajar analitik suka mengerjakan satu hal dalam satu kesempatan/ waktu. (7) seseorang yang bergaya belajar global tidak tepat waktu, kecuali pada peristiwa atau even yang penting, sedangkan yang bergaya belajar analitik (sangat) tepat waktu, (8) seseorang yang bergaya belajar global fokus kegiatan pada kreativitas,.sedangkan yang bergaya belajar analitik suka akan kerapian. (9) seseorang yang bergaya belajar global belajar dengan baik ketika informasi disampaikan dalam bentuk cerita dengan humor atau emosi,..sedangkan yang bergaya belajar analitik belajar dengan baik ketika informasi disampaikan dalam langkah/tahapan yang berurutan, (10) seseorang yang bergaya belajar global berbicara dengan gesture (gerak tubuh) sedangkan yang bergaya belajar analitik berbicara dengan sedikit gesture.

2. Temuan-temuan kajian tentang hubungan pembelajaran dan otak memperlihatkan berbagai hal baru yang dulu tidak pernah dipikirkan. Berdasarkan temuan kajian tersebut kemudian muncul berbagai teori otak dan pembelajaran. Teori otak yang sangat populer selama dua dasawarsa terakhir ini adalah teori Otak Triune "triune" berarti three in one. Menurut teori ini Meier (dalam Dryden, 1999), otak manusia mempunyai tiga bidang spesialisasi yang terpisah (meskipun saling berhubungan): Otak Reptil, Sistem Limbik (Otak Tengah), dan Neokorteks. (1) Otak Neokorteks adalah topi otak, penutup yang melilit berupa zat berwama kelabu yang merupakan 80 $85 \%$ dari massa otak. Fungsinya tingkat tinggi: berbahasa, berpikir abstrak, memecahkan masalah, merencanakan ke depan, bergerak dengan baik, dan berkreasi; sehingga manusia itu "unik", (2) Sistem Limbik adalah otak tengah yang memainkan peranan besar dalam hubungan manusia dan emosi; otak sosial dan emosional. Dlam otak ini juga terkandung sarana yang penting untuk ingatan jangka panjang, (3) Otak Reptil adalah otak paling sederhana (dinamakan demikian karena reptil pun memilikinya). Tugas utama otak ini adalah mempertahankan diri. Otak ini menguasai fungsi-fungsi otomatis, seperti degupan jantung dan sistem peredaran darah. Di sinilah pusat perilaku naluriah dan repetitif yang cenderung mengikuti contoh dan rutinitas secara membuta. Otak reptil dipercaya sebagai bagian otak yang terlibat dalam perjuangan kekuasaan hierarkis. Ia tahu cara menipu jika diperlukan demi kelangsungan hidupnya; dan fungsi otak ini sama dengan otak hewan.

Dalam proses pembelajaran, ketiga aspek otak tersebut bukan dilihat dari lokasi fisiknya, melainkan sebagai pusat kliring untuk fungsi-fungsi khusus. 
Tak satu pun dari ketiga fungsi kliring bekerja sendiri-sendiri. Semuanya saling berhubungan fungsi saling membantu guna menjalankan fungsi mereka. Sepanjang waktu di dalam otak terjadi pertukaran dan saling-bantu yang berlangsung terus-menerus antara otak Neokorteks: berpikir, belajar, memecahkan masalah, mencipta, dengan Sistem Limbik: sosial, emosional, ingatan jangka panjang dan Otak Reptil: naluriah, mengulang, mempertahankan diri

Dalam hubungannya dengan pembelajaran, Meiere (dalam Dryden, 1999) mengemukakan bahwa pembelajaran konvensional sampai dengan era industri cenderung menekankan fungsi reptil: belajar menghafal, meniru, guru aktif, siswa pasif, rutinitas, semangat mempertahankan diri (takut gagal), mengabaikan perasaan dan ikatan sosial, melemahkan kreasi dan memecahkan masalah, serta berpikir sendiri. (Pemikiran mandiri yang terlalu dibebaskan untuk pembelajar, sesungguhnya, dianggap subversif dan pembangkangan). Praktik pembelajaran semacam ini ternyata dijangkiti "penyakit". Karena itu dibutuhkan obat penyembuhnya. Menurut Meiere(dalam Dryden, 1999), gejala penyakit pembelajaran tersebut antara lain (1) puritanisme, yakni proses pembelajaran dikondisikan serius, seram, kering, kaku, dan berpusat pada guru. Obat penyakit ini adalah belajar yang menggembirakan, mengasuh, berpusat pada subjek belajar, dan mengembnagkan kemampuan belajar bagaimana belajar (learn how to lern), (2) individualisme akibat persaingan antara subjek belajar dapat terjadi karena keterasingan dan putus hubungan. Obatnya adalah menciptakan belajar yang dapat membangun kerja sama di antara pembelajar dalam komunitas belajar, (3) model pabrik, belajar jalur perakitan satu-ukuran-untuk-semua. Berdasar waktu dan patuh pada petunjuk. Obatnya adalah prasmanan berbagai pilihan berdasarkan hasil dan kreatif, (4) pemikiran ilmiah Barat, gejala penyakit ini adalah pendekatan belajar linier, mekanis, dan terkotak-kotak..Obatnya adalah pendekatan belajar holistik, kontekstual, dan saling berkaitan, (5) pemisahan pikiran/tubuh, gejalanya adalah belajar yang kognitif, verbal, menekankan otak kiri, dan pasif secara fisik. Obatnya adalah belajar dengan memanfaatkan seluruh otak, multi-indera, dan aktif secara fisik, (6) dominasi pria, gejalanya adalah tekanan pada kontrol, kecerdasan rasional, dan proses berurutan.. Obatnya adalah tekanan pada pengasuhan, kecerdasan seluruh otak, dan proses simultan dan (7) media cetak, gejalanya adalah belajar kata-kata dan konsep abstrak sebagai landasan belajar.Obatnya adalah belajar gambar dan pengalaman konkret sebagai landasan belajar.

3. Implikasi dari penyembuhan penyakit-penyakit pembelajaran tersebut kemudian menumbuhkan kepercayaan-kepercayaan baru pada satu sisi dan pada sisi lain meninggalkan kepercayaan lama tentang pembelajaran. Beberapa 
pergeseran perubahan dari paradigma lama menuju paradigma baru tersebut adalah (1) pada kepercayaan lama belajar adalah menyerap informasi sedangkan yang baru belajar adalah menciptakan makna, nilai, dan pengetahuan yang dapat dipraktikkan oleh pembelajar, (2) belajar adalah usaha individualistis, sedangkan yang baru belajar meningkat pesat di lingkungan sosial yang sarat kerja sama dan interaksi manusia, (3) pengetahuan terutama bersifat verbal dan kognitif. sedangkan yang baru pengetahuan melibatkan seluruh tubuh/ pikiran, emosi, indera, dan seluruh aspek kecerdasan, (4) standarisasi menghemat waktu dan uang sedangkan yang baru solusi satu-ukuran-untuksemua membuang-buang uang, (5) kita harus menguji ingatan jangka pendek sebagai bagian mempelajari program, sedangkan yang baru prestasi jangka panjang, bukan ingatan jangka pendek, itulah tujuan pembelajaran, (6) pembelajaran menuntut sistem penyampaian yang terkontrol sedangkan yang baru pembelajaran terhalang oleh terlalu banyaknya kontrol luar, hierarkis, dan strukturisasi. Belajar paling baik jika dilakukan dengan semangat kegembiraan dan permainan, (7) Belajar adalah urusan serius sedangkan yang baru Pembelajaran paling berhasil dalam lingkungan yang kaya-pilihan dan memberi banyak jalan.

\section{Peningkatan Kualitas Belajar dan Pembelajaran}

Untuk meningkatkan mutu dan kualitas hasil pendidikan peningkatan kulaitas proses belajar dan pembelajaran adalah menjadi suatu keniscayaan. Belajar dan pembelajaran terjadi jika terjadi pemrosesan informasi oleh peserta didik. Prosesnya bisa melalui persepsi, penyimpanan informasi, pemanfaatan dan penerapan kembali informasi yang diperoleh untuk memecahkan masalah yang dihadapi. Belajar merupakan kegiatan aktif pebelajar dalam membangun makna atau pemahaman dan pembentukan nilai-nilai. Karena itu dalam meningkatkan kualitas proses belajar dan pembelajaran dibutuhkan kemampuan penciptaan situasi dan kondisi belajar yang dapat mendorong prakarsa, motivasi, dan tanggung jawab pebelajar untuk terus belajar sepanjang hayat.

Brooks and Brooks mengemukakan lima prinsip belajar dan pembelajaran untuk membangun makna atau pemahaman dengan pendekatan konstruktivistik (1) menampilkan permasalahan aktual yang relevan dengan kebutuhan (2) menstruktur kegiatan belajar pada konsep utama, (3) mencari dan menilai titik pandang pebelajar, (4) mengadaptasi kurikulum sesuai kebutuhan dan (5) mengakses belajar dalam konteks pembelajaran yang bermakna.

Berdasarkan pandangan konstruktivistik tersebut, aktivitas belajar dan pembelajaran yang perlu dibangun dan dikembangkan dosen adalah menciptakan lingkungan belajar yang kondusif yang memungkinkan mahasiswa dapat belajar, satuan acara perkuliahan yang disusun mencerminkan proses aktivitas belajar 
mahasiswa dengan fokus pada kajian ilmu (konsep, hukum, dalil), isu-isu global yang relevan, dan eksplorasi sebagai pengembangan dan penggalian ide kreatifinovatif. Dalam proses belajar dan pembelajaran, dosen perlu membangun (1) sikap dan persepsi positif mahasiswa terhadap belajar, (2) berpikir bagaimana memperoleh dan mengintegrasikan pengetahuan baru dengan pengetahuan yang telah dimiliki, (3) selalu memperluas dan menyempumakan pengetahuan yang dimiliki, (4) penggunaan pengetahuan secara lebih bermakna, dan (5) pembiasaan berpikir produktif.

Beberapa prinsip pembelajaran yang dapat meningkatkan kualitas proses belajar dan pembelajaran adalah (1) berpusat pada pebelajar, yakni pengelolaan pembelajaran dapat membuat mahasiswa belajar sesuai karaktristik kemampuan, minat, kesenangan, pengalaman, cara dan gaya belajamya, (2) belajar dengan melakukan, yakni pembelajaran diupayakan yang dapat memberikan pengalaman nyata siswa untuk mengaplikasikan konsep, kaidah, prinsip, hukum, atau dalil dalam dunia nyata ( learning to do), (3) mengembangkan kemampuan social, yakni membangun kemampuan dan pemahaman dalam mengkomunikasikan gagasannya sehingga dapat mempertajam, memperdalam, memperluas, menyempurnakan gagasanya serta bersosialisasi menghargai perbedaan pendapat, sikap, kemampuan, prestasi, dan berlatih untuk bekerjasama.(4) mengembangkan keingintahuan, imajinasi, dan fitra bertuhan, yakni melatih modal dasar untuk bersikap hasil belajar adalah dapat meningkatkan ketaqwaan peserta didik (mengasah fitrah bertuhannya), membangun sikap kritis, mandiri, dan kreatif dan produuktif, (5) mengembangkan keterampilan pemecahan masalah, (6) mengembangkan kreatifitas peserta didik, (7) mengembangkan kemampuan menggunakan ilmu dan teknologi, (8) menumbuhkan kesadaran sebagai warga negara yang baik, (9) mendorong belajar sepanjag hayat, dan (10) membangun perpaduan kemampuan berkompetisi, bekerjasama, dan solidaritas.

Untuk dapat melakukan prinsip-prinsip tersebut di atas, dibutuhkan penataan atau pengelolaan suasana dan pengalaman belajar yang nyaman dan menyenangkan (joyfull learning), yakni penciptaan suasana pembelajaran aktif, kreatif, dan menyenangkan. Penyediaan pengalamn belajar menurut Peter dalam Dryden, perlu mempertimbangkan tingkat perolehan hasil belajar siswa berdasarkan kerucut pengalamnya bahwa kita belajar $10 \%$ dari apa yang kita baca, $20 \%$ dari apa yang kita dengar, 30\% dari apa yang kita lihat, 50\% dari apa yang kita lihat dan dengar, $70 \%$ dari apa yang kita katakana, dan $90 \%$ dari apa yang kita katakana dan lakukan. Hal ini menunjukkan bahwa jika pembelajaran banyak menekankan penerapan mode ceramah, maka perolehan hasil belajar sanga minim, yakni hanya terserap $20 \%$ karena siswa hanya mendengarkan. Sebaliknya, jika siswa diminta untuk melakukan sesuatu dan hasilnya diminta untuk melaporkan, mereka akan dapat mengingat lebih banyak $90 \%$. Karena itu penataan strategi atau metode belajar, pengalaman 
belajar maupun sumber atau media pembelajaran dipilih dari paling memungkinkan dapat meningkatkan kualitas hasil belajar dan pembelajaran, yakni berangkat dari pertanyaan "apa yang harus dilakukan siswa dalam belajar", jika tidak mungkin "apa yang dapat dijelaskan", selanjutnya "apa yang dapat dilihat", dan jika sangat terpaksa maka "apa yang dapat didengar dan dibaca siswa".

\section{Penutup}

Tranformasi belajar dan pembelajaran dalam upaya meningkatkan kualitas dan mutu pendidikan harus terus diupayakan sebagai konsekuensi dari tuntutan belajar yang sesuai dengan perkembangan ilmu pengetahuan dan teknologi, gaya belajar, perkembangan teori belajar dan pembelajaran, serta kebutuhan dan kecenderungan yang terjadi di masyarakat sebagai bagian perkembangan zaman. Transformasi belajar dan pembelajaran dimaksudkan untuk memberikan suasana, watak, dan pola-pola belajar yang pasif, tergantung dari satu sumber, fasilitas yang minim dan seadanya, gaya belajar yang seragam serta tidak memberdayakan peserta didik perlu dikembangkan menjadi pola dan sikap belajar yang mengembangkan keutuhan peserta didik secara aktif, produktif, dan proaktif dalam membangun learning to know, learning to do, learning to be, dan learning to live together.

\section{Daftar Rujukan}

Anne Abbeck, M. Warly Childhood Education. Australia: Longman Chesin. Anonim, 1994. Education in Asia and The Pacific. UNESCO:Bangkok Balitbang Diknas, 2002. Kurikulum Berbasis Kompetensi: Kurikulum Hasil Belajar. Jakarta: Pusat Kurikulum Balitbang Diknas.

Brooks, J.G. \& M.G. Brooks. 1993. The Case For Constructivist Classrooms. USA: ASCD.

Buchori, Mochtar. 2001. Pendidikan antisipatoris. Yogyakarta: Kanisius.

Djohar. 2003. Pendidikan Strategik: Alternatif untuk Pendidikan Masa Depan. Yogyakarta: Lesfi.

Dryden, G. \& Vos, Jannette. 1999. The Learning Revolution: To Change the Way the World Learns. Selandia Baru: The Learning Web.

Sudjana, Nana. 2000. Dasar-Dasar Proses Belajar Mengajar. Bandung: Sinar Baru Algensindo.

Tilaar, HAR. 1998. Beberapa Agenda Reformasi Pendidikan Nasional dalam Perspektif Abad 21. Magelang: Tera Indonesia. 